\title{
西欧製系技術の導入と工場制度の普及・定着*
}

——官営富岡製糸場の意義再考——

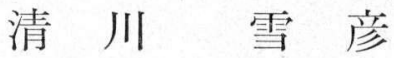

\section{1. 分析の視角}

明治以降，日本の製系業は急速に近代化の歩み を開始する。そしてその近代化を最る端的に表徴 するものとして，また初の本格的洋式技術を体現 した製系工場として, 明治 5 (1872) 年群馬県 (旧岩 鼻県)に設立された官営富岡製糸場の名は，市ま りにも有名である。だがいまその象徴的存在を越 え，実質的に富岡製糸場の果した役割となると， これまでのところ必ずしる十分に明らかにされて いないばかりでなく, 通説ではむしろ消極的評価 の方が支配的であったといってよい1)。

それというのも富岡製系場は，官営の“直訳的” 技術導入であったがゆえ，市場に十分適合的でな く且つまた冗費も多く, 経営的に多及樑刻な問題 を抱えていたこと。従って日本の製糸業の真の発 展は, むしろ洋式技術が伝統的座繰技術との折哀 により，いわゆる簡易器械製系技術として適正技 術(Appropriate Technology)化された後に初めて 開始されるという見方が，経济史の分野では最も 有力な見解である。その点に関しては, 我々も必 ずしも大きな異論はないもの〉，たが富岡製糸場 の意義を単に狭義の技術移転のみとして捉えるこ とには,いさっかの疑義を感じざるを得ないので ある。

なぜならば，確かに富岡製系場には最新の機械 設備や建築技術等が体化・導入されていたもの〉，

* 本稿は, 文部省の特定研究として助成を受けた 「工業化の戦略」に関する共同研究の 1 部分を構成す るものである。

1) 例えば古島敏雄氏の『産業史 III』(山川出版社 昭和 41 年) は秀れた啓蒙書であるが，そこでの富岡製 系場の影響力に対する評価(236-38頁)は, こうした否 定的なるの〉 1 例である。
要はそ机だけにとどまらず，当時の日本にとって 画期的な生産システムたるいわりる工場制度が同 時に移植されたからである。しかも全ての生産管 理はブリューナ(Paul Brunat)以下のフランス人 スタッフによって行わ机たのであった2)。すなお ちその当時，技術ならびに生産組織のすへてを西 欧流に管理・運営する生産システムとしてこの富 岡製系場に比肩しうるものは，わずかに横須賀と 長崎の官営製鉄 (造船) 所が在ったにすぎなかった のである。加えて富岡製系場の場合, そうした洋 式技術ならびに生産組織が，すでに相当程度の生 産基盤を持つ製系業という在来部門に導入された という点でもまた，その影響力の決定的な重要性 が見出されなけ机ばならないのである。

な打他方に扔いて, 洋式技術導入の重要性もさ ることながら，技術と組織 (以下管理面る含む)を 同時に工場制度という1つのパッケージとして導 入した点にこそ, 製系業における富岡製系場の ‘模範工場〉としての本質的意義があったと想定さ れる。それゅきそうした新しい視点に立つ時は じめて，これまでの富岡製系場に対する否定的評 価や従来な扢ざりにされてきた側面に対してもま た，新しい光が投げかけられうるものと判断され よう。

例えばまさにこの点に扔いて富岡製糸場は，同 じ頃西欧製系技術の導入を図った前橋製糸所や築 地製糸場, 赤坂勧工寮製系場などとは基本的に区 別されねばならない一方，ましてや従来の座繰な

2) これまで富岡製系場関係者をはじめとする外国 人名の綴が示されることがなかったため, しばしば混 乱を招いている。原経については, 拙稿「富岡製系場 関係外国人の人名について」『奛糸科学と技術』第 25 巻第 10 号 (近刊)を参照されたい。 
いし改良座繰製系との間には，生産システムとし て本質的に大きな差異が存在していたことを指摘 して扔く必要があろう。そのことは同時に，工場 生産の概念を明確にすることにより，これまでの 座繰“大工場”の本質をめぐる議論に対しても, 我々なりの見解を引き出し得ることを含意してい る。

なお日本における工場制度の普及の問題を考察 する際，製糸業の経験がきわめて有意義な役割を 果しうることは，改めて指摘するまでるなかろう。 そ机というのも 1 つには，製系業では本格的な工 場制度の導入が，きわめて早い時期に行われたか らである。こ机は戦前日本のもう1つの主要な産 業たる綿紡績業の事例と比較しても十分に早かっ たといってよい。特に後者の場合, 大阪紡設立 (明治 17 年)以前の官営紡績や十基紡等は，まだ 紡績工場としてその規模や技術・組織に不確定な 要素が強く, 必ずしもその後の工場制度確立の原 点とは見做し難い点が多かったからである。また 2 つには製糸業の場合, 造船業や綿紡績業とは異 なり，工場制生産の普及が特定の地域や港湾都市 に偏ることなくほ心゙全国各地に及んだがゆ，工 場制度と日本の社会全体との相互規定的な側面な ぞを考察する際，特に適切であったと考えられる ことである。

ところでこの工場制度の普及は, 製系業自体に 扮いて子決定的な意味を持っていたことはいうま でもない。すなわち恒常的な生産体制たる工場制 度の進展とともに, 製系業はそれ以前の季節的な 生産から脱却し, 養虫業との分離独立をる推し進 めたのである。その結果, 多数の繰糸専従工が必 要とされ, 各地の若年女子労働力は製系業地への 移動を促されることにより，次第に広範な女子労 働力市場が形成されるに到った。他方製系業の発 達はまた，当然原料供給部門の養寔業にも，供給 の拡大とりわけ夏秋虫作の発達を強く迫ったこと を意味していた。事実，明治の中期以降夏秋㔻の 生産は急激な増大をみせ, 農作業の労働供給にす ら大きな変化が生じている。さらには農村におけ るそれまでの稲作中心的社会生活や年中行事にも また，次第に大きな影響が出始めるのである3)。
このように工場制度の急速な展開を伴った製系 業の発展は, 日本経済の様々な側面に著しい直接・ 間接の影響を与えつつ市ったといってよい。それ ゆえいま我々は, そうした変化の根底に介在して いた最も基本的な要因たる工場制度の普及・定着 という問題を, 富岡製系場の設立すなわち西欧的 製系工場生産方式の導入とその意義という側面に 限定して検討する。あるいはより具体的にいえば, 本稿は次のような 2 つの分析課題を有する。まず

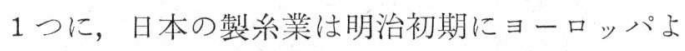
り，技術と組織を 1 つのパッケージとした工場制 度なる生産組織の形態を導入したが，それは日本 経済ないし製糸業界にどのように定着していった のか，あるいはまた逆に日本の社会や文化から如 何なる影響を受けたのかを，ファース(Raymond Firth)の仮説を念頭に招さながら検討したい4)。

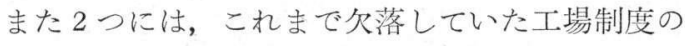
移植という観点を導入した場合にもなお，富岡製 系場の建設は, やはり日本製系業の近代化にそれ ほど大きな意義を持ちえなかったのか不かを確認 することである。

今これらの目的のために, まず第 2 節では, 富 岡製系場の生産組織としての画期的な性格を確認 する一方, 製系業に扔ける日本的工場形態の確立 (概ね明治 30 年代末頃と考える)ならびにそれに 符合する形での富岡製系場自身の変容過程を捉え る。次いで第 3 節では, 工場生産としての器械製 系工場の本質的意義を確認したうえ, 富岡製系場 の工場制度の普及に果した役割を捉えるべく，個 別的事例のみならず, 各県の伝習工女派遣等と大 型器械製系工場建設との間の相関関係を, 簡単な 符号検定によって検証する。また第 4 節では，曆 制の改革に伴う日曜休日制を 1 つ事例として, 工場制度の背後に存在したヨーロッパ文化の移植 に対する工場ならびに社会の反応とその受容過程

3）養虫製系の興隆が農村生活に多大な変化を与一克 たことは, 例えば柳田国男(編)『明治文化史 第 13 卷 風俗』(原書房 昭和 54 年), 396-402 頁 (大藤時彦執 筆)なぞを参照のこと。

4) Raymond Firth, Primitive Economics of the New Zealand Maori (George Routledge \& Sons, 1929) の第 14 章を参照のこと。 
を検討するであろう。

\section{2. 富岡製糸場の画期的性格}

\section{富岡製糸場の技術と組織}

富岡製系場についてはここれまですでに『富岡 日記』をはじめ多くの著作が著わされ，その実態 に関してはかなり詳細に知られている5)。また同 製糸場に関する記録や統計など関連資料のほとん どすべては，『富岡製系場誌』に収録されている がゆえ゙),ここでは我々の議論に必要な限りに扔 いてその技術や管理形態に言及することとする。

明治 $3(1870)$ 年 8 月, 富岡が工場建設地に指定 されるとともに用地の買収や建築資材の調達が直 ちに開始され,ほよ゙ 2 年後の 5 年 7 月には, 横須賀 製鉄所の製図工バスティアン(Edmond Auguste Bastien)の設計と初代場長尾高惇忠の監理の下で， 初の本格的洋式工場が竣工する。この間技師長た るブリューナは一時フランス本国へ帰国し，ガラ スから戸締り具に到るまでの洋風建築資材と製系 器械ならびに蒸気鑵等の設備一式を購入する一方, フランス人技師 3 名と製系教婦 4 名を雇い入れ，

明治 5 年 2 月共に着任している。

製系工場の建設にあたっては, レンガの製造や セメントの代用品たる漆喰の生産等に多少の困難 を感じたるの〉，2階建(木骨)レンガ造りの工場 は典型的フランス風工場建築であり7), 当時の日 本の建築水準からみれば，実に機能的かつ壮大な ものであったことは疑いない。またそこに設置さ れた 300 鉒にも及ぶ繰系器械は, 堅牢な鉄製機械 でその駆動には，石炭による蒸気力が利用された。

5) 和田英『富岡日記一富岡入場略記 - 六工社創立 記一』(東京法令出版 昭和 40 年), 藤本実也『富岡製 糸所史』(片倉製系紡績株式会社 昭和 18 年), 富岡史 編纂委員会(編)『富岡史』(富岡市役所 昭和 30 年) 701 -815 頁, 上條宏之『絹ひとすじの青春』(日本放送出版 協会 昭和 53 年)なぞ。

6)富岡製系場誌編纂委員会(編)『富岡製系場誌 (上) (下)』(富岡市教育委員会 昭和 52 年)。

7) 例えばそれは，永井保興『製系家必携(中)』(有 隣堂明治 16 年)なぼからる窺われよう。また Pierre Cayez, Crises et croissance de l'industrie Lyonnaise 1850-1900 (Centre national de la Recherche scientifique, 1977)なども参照のこと。
なお繰糸法は, 募繰兼業の浮繰法で 2 口取りの共 撚(Chambon) 式繳掛装置が採用されている。そ の他乾荋殺蛹には，蒸殺法と熱風殺蛹法を折表し た蒸燥殺法が用いられ，また枠揚げは座繰製系法 の場合と同じ小枠に一担繰揚げた後, 再び大枠へ 揚返す再繰方式が独自に開発・採用されている。

こうした富岡製糸場の洋式技術は，日本在来の 手挽きや座繰製系法と比較する時8)，はるかに生 産性が高く且つまた糸質優良な生糸を生産し得た ことは，贅言を要すまでもなかろう。なぜならば まず第 1 に, 繰枠の回転に動力を利用することに よって繰系工の左手 (ないし右手) が解放され, 両 手をるって完全に索緒と添緒に専念することが出 来るようになったからである。しかもその繰枠の 回転はきわめて規則的であり，かつ他の鉒と相互 に連結されていたがゆえ, 均質で品位の高い生系 が同時に大量生産されたのである。また第 2 には, 集緒器と繳掛(抱合)装置が導入されたことにより, 繊度が斉一で抱合の良い糸の生産が可能となった ことである。それらの装置は機械的にはごく単純 な仕掛けであるにもかつわらず, 奥州座繰の“毛 つけ’などとは比ぶべくるなく糸質の改善に貢献 したのである。

だがこうした技術的優越性は何子富岡製系場だ けに限られたことではなく，また必ずしも同製系 場の真の画期的性格でるなかったと我々は考える。 なぜならばスイス人ミューラー(Caspar Müller) の指導の下で設立された前橋製糸所 (明治 3 年) や 築地製系場 (明治 4 年) あるいは勧工寮製系場 (明 治 6 年)に扔いても, 上記の 2 点は同様に満たされ ていたと判断されるからである。るっとるこれら 3 工場は, ケンネル(Tavelette) 式繳掛装置を備え た煮繰分業の直繰式簡易工場で，いわゆるイタリ アの家内工業的製糸工場の移植であったと想定さ れる。それゆえごく小規模で，炭火を熱源とし動 力は人力に依っていたから, 繰枠の回転や煮蔝・ 繰系湯の温度等の安定性の点で，富岡製糸場に一

8)座繰技術については，加藤宗一『日本製系技術 史』(製系技術史研究会 昭和 51 年) や高橋清七『群馬 の座繰製糸指針』(有隣堂 明治 42 年)などを参照のこ Ł。 
歩譲ったもの১，座繰製系に比べればはるかに良 質の生糸を生産しえたのである。

いいかえれば我々は富岡製系場の真に画期的な 性格を，その技術面よりはむしろ厳格な生産管理 を伴った工場制生産という生産システムえのるの のなかに見出しうると考える。つまり秀机た系質 の 5 粒付け 12 デニール系を生産すべく, フラン ス人スタッフの下でョーロッパ的工程管理や品質 管理・労務管理が積極的に導入され，専業化した 各部門間の連携や職務権限の異なる複数階層間の 機能的結合が有機的に統合された $1 つ の$ 典型的工 場生産がそこには体現されていたからである。

例えば 300 釜という当時としては著しく大規模 な繰系部門では，25 鉒に 1 人の製系教婦(日本人 も一部担当)が，また 50 鉒每にさらに 1 人の繰糸 監督が付き, 各工女に添緒や煮藏の助言・指導を 行う一方, 繰体回転速度の調整や惹絧・繰系湯の 温度管理等の基本的工程管理をも分掌したことが

\section{第 1 表 製糸工場の機械設備と生産管理の比較}

\begin{tabular}{|c|c|c|c|c|}
\hline & & $\begin{array}{c}\text { (1) } \\
\text { 官営富 岡 } \\
\text { 製 系 場 }\end{array}$ & $\begin{array}{l}(2) \\
\text { イタリア・フ } \\
\text { ランスの器械 } \\
\text { 製系工場1 }\end{array}$ & $\begin{array}{c}\text { (3) } \\
\text { 日本の標準的 } \\
\text { 器械齔系工 } \\
\text { 場2) }\end{array}$ \\
\hline 1 & 工場規模 & 300 釟 & 50-150 鉒 & 50-150釜 \\
\hline 2 & 工場建築 & $\begin{array}{r}\text { 大規模・レンガ } \\
\text { レン }\end{array}$ & レンガ & 簡易・木造 \\
\hline 3 & 原 動 力 & 蒸気 & 概ね蒸気 & 水力 \\
\hline 4 & 機械の素材 & 鉄製 & 鉄製 & 木䌘 \\
\hline 5 & 繳掛装置 & 共撚式 & $\begin{array}{l}\text { 概ねケンネル } \\
\text { 式 }\end{array}$ & ケンネル式 \\
\hline 6 & $\begin{array}{l}\text { 緒数と竟繰 } \\
\text { 法 }\end{array}$ & 2 緒・康䓺 & $\begin{array}{l}4 \sim 5 \text { 緒・ } \\
\text { 概ね分業 }\end{array}$ & $2 \sim 3$ 緒・兼嶪 \\
\hline 7 & 枠揚 げ & 再絽式 & 直繰式 & 再綝式 \\
\hline 8 & $\begin{array}{l}\text { 主要亦品の } \\
\text { 緎度 }\end{array}$ & $12 \mathrm{D}$ & $10-12 \mathrm{D}$ & $14-17 \mathrm{D}$ \\
\hline 9 & 主な市場 & 輸出用 & 国内消費 & 輸出用 \\
\hline 10 & $\begin{array}{l}\text { 年間稼動日 } \\
\text { 数 }\end{array}$ & 280-290日 & $240-260$ 日 & 230-280 日 \\
\hline 11 & 休 日 制 & 日曜・週休 & 日曜・週休 & 月 2 回 \\
\hline 12 & 寄宿舍制度 & 完備 & 通勤工多し & 概ね寄宿工 \\
\hline 13 & 㕍用期間 & $\begin{array}{l}\text { 原則として } 3 \\
\text { 年 }\end{array}$ & 年契約・ & 1 年更新 5 年 \\
\hline 14 & 工女の年椧 & $15-20$ 歳 & $15-20$ 歳 & $15-20$ 歳 \\
\hline 15 & 労働時間 & 8-9 時間 & 11-12 時間 & 13-14 時間 \\
\hline 16 & 夜業 & なし & 繁忙期にあり & 概ねなし \\
\hline 17 & 監督制度 & ヨーロッパ流 & 指導細心 & 厳格 \\
\hline 18 & 賃金体采 & 等級別時間給 & 概ね時間給 & 出来高給 \\
\hline 19 & 賞罰制度 & 概ねなし & 概ねなし & 絩格 \\
\hline
\end{tabular}

資料：本文の脚注文献を中心にまとめられている。

注： 1) 19 世紀後半の状況を主に想定。

2) 明治 30 年代の状況を主に想定。
知られている。るとよりそうした系質重視の生産

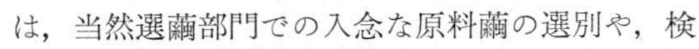
查部門における厳格な品質查定, あるいは束装に 際しより公正な取引を可能ならしめる肉眼検査容 易な捻造りの採用など，生産工程全般にわたる品 質管理にも十分意が用いられていたことを意味し ていたことはいうまでるない。また全国各地より 応募した伝習工女達は, 寄宿舎で起居するととも に，その高い集中力を要した製系労働は，時計に よる規則正しい時間管理の下で，常時集団的に標 準化された動作や作業が要請されたのである。つ まりこのような総合的にシステム化された集団作 業による分業的生産形態は, 当時の日本の製糸業 に在って全く画期的な生産体系の出現であったと いっても決して過言ではないと考えられる。

\section{フランス・イタリアの製糸工場との比較}

以上のような富岡製系場の技術や組織に関する 特質は，いま第1表にまとめら机ている。そこで 次にそ机らを, 19 世紀後半のフランス・イタリア の製系工場一般と比較することにより，富岡製系 場の近代性ないし西欧的性格を改めて確認してお こう。な扔フランスやイタリアの平均的製糸工場 の特質は, 多少の異論を覚悟のうえでごく単純化 すると, 第 1 表第 (2) 欄の如くにまとめら机ると 思われる9)。この比較を通じ, 富岡製系場の機械 設備や技術・生産管理に関して，少なくとも次の 3 点が指摘されうるであろう。

まず第 1 に，第 1 表からも明らかな如く，富岡 製系場はョーロッパの製糸工場と比較して，その 規模や機械設備の点で何ら遜色ないばかりか, む しろその平均よりるはるかに優る設備を擁してい

9) Natalis Rondot, Les Soies (Imprimerie nationale, 1885), Noel Vermont, Notes sur l'art de filer la soie (Moniteur des soies, c 1903), Thomas Wardle, Kashimir (Simpkin, Marshall, Hamilton, Kent \& Co., 1904), Leo Duran, Raw Silk(Silk Publishing Co., 1913), Hans Tambor, Seidenbau und Seidenindustrie in Italien (Verlag von Julius Springer, 1929)などのほ か, 邦書では高橋信貞『欧米蟇業一班』(原合名会社 明治 33 年), 今西直次郎『今西生系検查所技師 欧米 亘系業視察復命書』(農商務省生系検查所 明治 35 年), 石渡繁版『伊仏墺菙系業視察復命書』(農商務省農務局 明治 38 年)などを参照。 
たことが知られる。フランスやイタリアとりわけ 後者には, 水力や人力を動力とし寵型直火加熱式 の $10 \sim 30$ 釜程度の小規模製糸工場が多数存在し たから，全体の平均規模もまた 19 世紀後半を通 じ，40〜60 鉒程度と著しく小さかったのである。 な打両国の蒸気力による近代的製糸工場をとって ๖,やはりその大部分は 50〜150 鉒規模であった といわれ10)，300鉒を超えるものは必ずしも多く はなかった。しかし両国には，撚糸部門を併設し たきわめて機械化の進んだ近代的な大規模製糸工 場が少なからず存在していたから，富岡製系場は むしろそうしたョーロッパでも最も先端的な製系 工場の技術と経営管理方式を導入すべく努めたと 考えられるのである。

また指摘さるべき第 2 点は, 富岡製系場に導入 された技術はフランス式として，イタリア式との 相違点が過度に強調されることが多いが11)，最も 肝要なことは両者の技術的な差異ではなく，富岡 製系場に移転された生産形態が，ヨーロッパの近 代的工場制生産方式であったという点に在ると我 我は判断する。すなわちいいかえれば，すでにも 指摘した如く，前橋製系所や築地製系場に導入さ れた技術や組織は，イタリア式というよりはむし ろョーロッパに扔ける在来的な家内工業的生産形 態であり，その点に扔いて富岡製系場のそれとは, 全く異なっていたのである。確かに19 世紀中頃 までのフランスの製系業は, 共撚式繳掛装置を多 く用い,イタリアに比へ之市糸質優先の生産方式 を採っていたといえよう。しかしながら19 世紀 の後半には, フランスでも繳掛装置は大部分ケン ネル式に改めら机, 募繰兼業方式も索緒工の導入 によって分業式へと切り換えられつ〉あった ${ }^{12)}$ 。

10) 今西直次郎前掲書, 79 頁执よび 82 頁，また Natalis Rondot 前掲書，69-71 頁扔よび 107-108 頁の ほか脚注 8)の文献を参照のこと。

11）例えばその典型として, 岡村源一『製系原料論』 (明文堂 昭和 7 年) 4-7 頁などの見方がある。また Leo Duran の前掲書るこの立場に近い。

12) Louis Gueneau, Lyon et le commerce de la soie (Universite de Lyon, 1923), pp. 109-12. Noel Vermont 前掲書, 第 $9 \cdot 10 \cdot 15$ 章; Thomas Wardle 前掲 書, 117 抢よび 197 頁; 石渡繁扸前掲書, 93 頁; 今西 直次郎前掲書, 97 頁; 高橋信貞前掲書, 17 頁等々に散
さらに殺蛹もまた貯絧期間を考え，一部では蒸殺 から燥殺に変えられるなど，フランスの製系技術 は急速にイタリアの近代的製系技術に接近しつ〉 あったのである。従ってもし両者の相違を強調し ようとするなら，それは技術的な差異ではなく， 日本ではイタリアより在来的なまたフランスから は近代的な工場生産の形態が導入されたといわね ばならないのである。

第 3 に，富岡製采場の労務管理や生産工程管理 は，基本的にヨーロッパ流のそれに則っていたと いえるが，同時にそこにはすでに早くも将来の日 本的労働強化型労務管理人の萌芽もまた見出すこ とが出来よう。たよ゙一般には, 官営模範工場とし ての富岡製系場の労働条件は, ヨーロッパのそれ よりも短い 8 時間労働に加え, 日㬦週休制が導入 されたほか，寄宿舎の居住条件や食事等も，当時 としてはほ心゙満足すべきものであったと考えられ る。しかし明治 7 (1874) 年には，早くもそれまで の 3 段階等級別時間給貢金が 7 段階に改められる など，コーロッパよりきめ細い賃金体系が制定さ れている。こうした緻密な労務管理化への傾向は, その後も一層強化されるが，そるてもそれを可能 ならしめた 1 つ技術的条件は, 日本の場合， そ の再繰式繰糸法に求められるといってよかろう。

すなわち再繰式の場合には13)，検査用糸を小枠 からの揚返しに際して，任意の回数だけほぶ任意 の個所から採取することが可能なため，その繊度 や類節の検查をいくらでも厳密化することが出来, かつまたその結果によって繰糸工個人の技量をよ り容易に評価することが可能であった。従ってこ こに，その後の箃格な賞罰制や系質に準じた出来 高給制が採用されてゆく っても決して過言ではないのである。いいかえれ ばそれに対して，直繰式を採用していたョーロッ パの場合，繰系工個人の技量の強化や評価には限 度があり，生産性の改善は勢い機械化志向的にな

\section{見される。}

13) 再繰法と直繰法の技術的な相対的長所は, 前者 は枠角の固着が少なく絡交も整然としており，また揚 返しに際し細班部分の除去が可能。それに対し後者で は, 揚返し部門の諸設備や工女が不要であり,また 2 本揚などの惧れがないことである。 
らざるをえなかったのである14)。

\section{工場制度の定着過程における変容}

いま富岡製系場自身の技術や管理のその後の変 遷過程に触れる前に, 次の重要な 2 点だけは確認 して打く必要があろう。まず第 1 に, 明治の初め ヨーロッパより導入された新しい器械製系技術は, その後明治 10 年代の中頃から 20 年代末にかけて 簡便化され，日本独自の適正技術として確立する とともに，着実な普及を開始したことである。す なわち明治 20 年代の後半には, 水車を動力源と し, 蒸気加熱による煮矮と繳掛装置を備えた木鉄 製器械による繰系を基本とする簡易器械製系技術 の類型がほ心゙固まり，大勢を占めつつあったとい えよう15)。このように著しく簡便化された日本の 器械製系技術は, 日本在来の座繰製系法とヨーロ ッパの家内工業的製系技術ならびに近代的器械製 系技術の 3 者を折表した 1 つの適正技術であった と考えられる。な扔えうした適正技術が，比較的 短時日のうちに成功裡に生みだされ得たというこ とは，ヨーロッパより移転された技術と日本の在 来技術との技術格差が，㹨義の技術に関する限り （すなわちその生産形態の問題を別として），あま り大きくなかったことを意味していたといっても よいのである16)。

第 2 に，明治 20 年代末頃までに上述のような

14) ヨーロッパの製糸業における機械化の動向につ いては, H. Silbermann, Die Seide (Gerhard Kühtmann, 1897) の第 4 章ゃ Achille Provasi, Filatura e torcitura della seta (Ulrico Hoepli, 1905 \& 2 ed., 1923)の 第 III 部などからも十分に窺われよう。

15）例えば，明治 26 年の『第 1 次全国製系工場調 查表』(農商務省農務局明治 28 年)の器械製系には, 人力によるあるいはまた炭火加熱による工場が多数含 まれていたが，それらは29年の『第 2 次全国製系工 場調査表』(同上 明治 31 年) では急速に減少している。 こうした ‘工場”概念一般の実態分析に関しては, 松田 芳郎・宇野富美子・佐藤正広「工場生産の普及と之の 意味」(南亮進・清川雪彦(編)『日本の工業化々技術発 展』東洋経済新報社近刊, 所収)などを参照のこ と。

16）技術格差仮説については，拙稿「技術格差と導 入技術の定着過程」(大川一司・南亮進 (編)『近代日本 の経済発展』東洋経済新報社 昭和 50 年, 所収) 打上 び同「日本の技術発展一その特質々含意一」(南亮進・ 清川雪彦(編) 前掲書, 所収)などを参照されたい。
適正技術の形態がほら゙固まった一方，その頃から 明らかに 1 つ日本的特色とでもいうべき共通性 をもった工場制度の型が，普及確立してくるので ある。すなわちそれは，第 1 表第(3)欄にも示さ れている如く，少ない休日と長時間労働を基本的 特徵とし，かつ検番・教婦による㛜格な監督制度 と，精緻な賞罰規定を含む競争督励的出来高給制 度 (時間給制も 1 部に併用)を根幹とした労務管理 ならびにその組織形態であったといえる17)。ある いは言い換えれぱそれは，生産量の急速な拡大や 品質管理の高度化を, 労働強化ないしは労働力 の転嫁によって解決しようとする日本的工場生 産・管理の形態であったといってもよいのである。 それゆえそうした特質は，太物中心の対米輸出の 拡大や夏秋寔の急速な発達など輸出市場や原料市 場の発展と相俟って, 明治 30 年代の末頃までに ほら゙形成されたと考えられるのである。なお他方 で，明治 40 年頃を境に，それまでの座繰製糸が 技術的には急速に器械製糸人と転換してゆく事実 ๒，この日本的工場制度の確立との関連に扔いて また，指摘さ机る必要があるかと思われる。

以上のような日本の製糸業全体の動向と, 富岡 製糸場の経営管理の変遷も，決して無関係ではな かったのである。すなわち同製糸場は, 明治 26 (1893) 年に三井へ払下げられた後，35(1902) 年に は再び原合名に譲渡されるのであるがこうした 民営化とともにその経営管理は、はっきりと製糸 業全体の日本的な工場管理形成の動问と軌を一に していたことが知られる。例えば，官営時代日曜 週休制であった休日は，1の日の月 3 回に減少さ れ，労働時間もまた る。一方, 従来原則的に 3 年であった雇用契約期 間は ${ }^{18)}$, 継年季手当の支給とともに 5 年に延長さ

17）ここでは一応 50 鉒程度以上の工場を念頭に置 いている。またいわゆる等級貢金制については，石井 宽治『日本虫系業史分析』(東京大学出版会 昭和 47 年)の第 3 章などを参照のこと。なお賞罰規定におけ るZero-sum 的貨金の加減法は, きわめてユニークな 日本的制度であるが, より本質的な側面は, 出来高給 制の徹底化というところに求められると我々は考える。 18）早期退場を願い出る者が多く，この期間は必ず しも厳格には守られなかったが, 通常繰系技術の習熟 には，2〜2.5 年を要するといわれていたので，伝習期 
れ，雇用の安定化が図られている。また明治 31 (1898)年には，繰系工の貨金に目取法と呼ばれた 出来高給制度が導入されるなど，明らかに厳格な 日本的労務管理のシステムに近づきつつあったと いってよい。

他方技術に関しても，主要製品がアメリカ向け 14〜15 中第になったこともあり，明治 29(1896) 年以降, 共撚式繳掛装置は漸次ケンネル式 $(3 \sim 4$ 緒取り)に置き換えら机ていったのである。また 注目すべきことは，明治 34(1901) 年以来主に落 㡀を挽く目的で座繰器が導入されただけでなく， 早くから鉒掛けにより 1,000 鉒を超える(明治 30 年代後半) 座繰糸の生産が内部化されていたこと である。つまりこのことの含意は恐らく，第 1 図 の等生産量曲線 (品質差調整济)にる示されている 如く，あまりにも高すぎた富岡製系場の資本 - 労 働比率を座繰生産との結合によって，多少とも最 適な比率の方向へ近づけようとする試みであった と解されるのである19)。このほか 30 年代末頃か らは，乾䠒・用水設備の改善や蟇種の無償配布市 るいは養虫指導巡回員の派遣や 1 代交雑種の採用 （44 年）なぞ，原料茛の改善面を中心に様々な技

\section{第1図 富岡製糸場の組織・管理面における適応化}

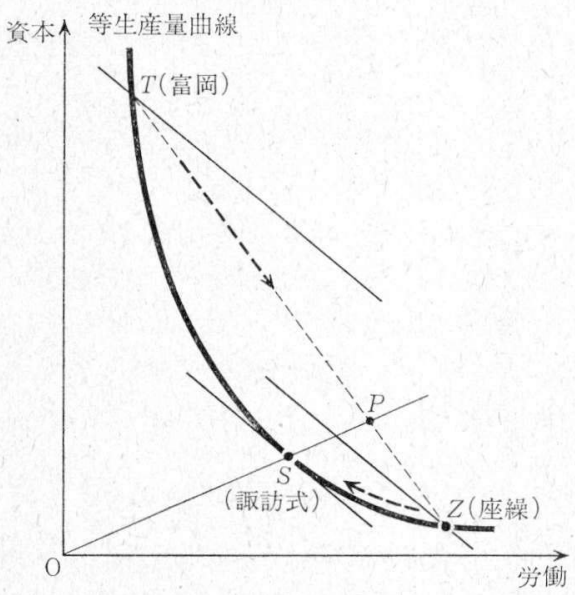

間 3 年というのは適切であったと考えられる。

19)座繰器の設置や釜掛け制の導入が経営的に有利 であった以上，当時の相対要素価格で評価すれば， $Z$ は $T$ の内側に在ったと考えられる。また $Z$ 自身には 簡易器械化の動きがあったから，Sの外側に在ったと いえよう。
術革新が積極的に取り入れられている。いずれに せよこうした一連の動きは，かなり過大な機械設 備を擁した富岡製系場の当時の市場条件に対する 積極的な適応化作用であったと理解されうるので ある。

\section{3. 工場制度の普及と富岡製糸場}

\section{新しい生産システムとしての器械製糸工場}

近代的工場制度としてョーロッパより移転され た新しい製糸技術とその生産組織は，日本の製糸 業において簡易器械製系技術ならびに日本的な工 場生産・管理として, 明治 30 年代の末頃までに ほ心゙定着したことはすでに指摘した。そこで本節 では，そうした工場制度の普及に際して富岡製糸 場の存在は，果して本当に何の意義を有さなか ったのか否かを簡単に検討して扔きたい。そのた めにはまず，新しい生産システムとしての工場制 度の概念の確認から始める必要があろう。

一般に「工場法」などの法律では，工場なる概 念はその従業員規模と原動機の有無によって規定 されることが多い。るとよりぞうした便宜的定義 では，生産システムとしての工場制度の本質は捉 え難いと思われるが，乙かしそれにはまたそれな りの意義もあるものと考えられる。すなわちそこ での従業員規模は，組織の複雑性を表わす指標と して，また原動機の有無は技術水準を表わす $1 つ$ の指標とる解されうるからである。いま我々るま た，そうした工場制度を技術と組織の両面から捉 える立場を採るのであるが，たぶ工場の概念を工 場対非工場に分割する二分法的定義は避けたいと 考える。いいかえれば，効率性の基準からその生 産組織としての有効性を連続的に把握可能(少な くとも論理的には)にするシステム論的視点が導 入さ机る必要があると思わ机る。

すなわち工場とは，市場条件一の適応化を前提 とした財やサーヴィス・情報の投入を産出に変換 する典型的制御システムの1つであると理解され る。従ってシステムとしてのいくつかの特性, 例 えばいわゆる統合性や階層性あるいは機能分化や 有機的構成などの特性が，そこには観察されよう。 またシステム内の階程には，その制御範囲に応じ 
て作業現場 - 生産工程 - 部門組織 - 工場経営など が, そして人的機能に応して操作・処理 - 管理 意志決定などがあるといえる。あるいはもっと端 的にいえば，制御システムたる工場組織は，分業 の進展や機能の多様化によってその効率性の改善 を図りうる生産組織に他ならない。従ってシステ ムとしての水準や態様は，そこに含まれる(1)人 的資源の質や (2) 技術水準によって規定されると ともに，外的条件である(3)市場の発達度によ。 てもまた左右されることはいうまでもない20)。

そ机ゆえいま前 2 者について座繰製系と器械製 系を比較すれば，その生産システムとしての質的 差異は歷然としていたと考えられる。すなわち技 術的には, 先にも指摘した如く, 動力の種類や繳 掛装置の有無あるいは蒸気加熱の採否等々に明確 な差異があったが，それだけにとどまらず，組織 面に扔いてもその分業化の進展度や管理組織の階 層化の程度, つまり換言すれば人的資源の専門化 や機能化の程度に扔いて, 両者には大きな相違が 存在したといえよう。その結果, 組織全体の統合 性や機能的構成力などにも差が生じ，システムと しての能率や効率に大きな相違を生む結果になっ ていたのである。

事実座繰製系は，明治の 10 年代㐨よび 20 年代 には結社(組合)を組織し，共同出荷や共同揚返を 行いあるいは器械製系に倣った捻造りを採用する など品質管理面で市場条件への適応化に努め, そ れなりの成果をあげたといえよう。しかしやはり 生産システムとしての脆弱性は覆いえず21), 明治 40 年頃から多くが技術面では器械製系方式に転

20）例えぱすぐに，下請制度とか産業組合組織とか 同業組合制度といった問題が念頭に浮ぶであろう。こ こでの工場は, 少なくとも複数の分業部門と複数の管 理経営層が存在する状況を想定している。なお制御之 は, 特定の目的に適合するように, 対象に所要の操作 を加えることを意味する。

21）座繰「大工場」の実態については, 石井寛治前 揭書, 第 3 章第 3 節などを参照のこと。なお我々は, 共同揚返所や共同出荷所を中心にした座繰経営組織を 工場と見做すことに同意出来ないばかりでなく，末端 工場が器械化されたその後の組合組織もまた, 制御シ ステムとして通常の工場制度に比へ, 管理面で種々劣 っていたと考える。
換している。だがその組織面での改善がない限り やはり競争力は弱く, 昭和初期へむけてそのマー ケットシェアは，大幅に低下したのであった。つ まり観点を变えれば，たとえそれが日本的に多少 矮小化されていようとも, 工場制度・組織の持つ ポテンシャリティは大きく, その意味で我々は器 械製糸工場の普及という問題にどうしても固執せ ざるをえないのである。

\section{器械製糸工場に関する情報の普及伝播}

日本的な簡易器械製系技術は, 明治 20 年代の 終り頃までにほら゙形成されたこと，またそれに際 してイタリアやフランスより導入された器械製糸 技術が大きな役割を果したことは，広く知られた 事実である。た ここれまでの議論にあっては，そ の適正技術の派生をめぐってあまりにもイタリア 式かフランス式かといった技術の表面的形態の問 題に論議を集中しすぎてきたきらいがある。その 結果，竟繰法や繳掛装置の種類等々を越えたより 本質的な問題が看過されがちであったといっても 決して過言ではなかろう。つまりそこには機械設 備の問題たけでなく, 工場組織の運営や労務管理・ 品質管理等々の経営・管理の問題も含まれ, 工場生 産という新しいシステムを採用するに当っては, 後者の問題もまたきわめて重要であったと考えら れるのである。そして今もしそうした側面にめ十 分な関心を払打うとするなら, やはり我々は唯一 本格的な工場生産の形態をとっていた官営模範富 岡製糸場の問題にたち㷌らざるをえないのである。

例えば福島の二本松製糸所や長野の深山田製糸 場の如く (とるに水車利用), イタリア系在来技術 による製糸工場でも，比較的規模の大きなるのが 全くなかったわけではないが，一般には小規模な ものが多かったといってよい。なぜならばある程 度の規模以上の工場を建てようとすれば，水車動 力の利用や蒸気による加熱は必要不可欠であり, 人力や䆠直火式のイタリア家内工業的技術では不 可能であったからである。それゆえその意味で, もし一定規模以上の製糸工場を建設しょうとする なら,どうしても富岡製糸場に関する情報は, 直 接ないし間接に必要不可欠であったと考えられる のである。その場合機械設備に関する情報や知識 
事実そうした含意

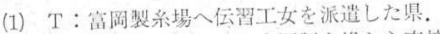

(2) ○：経営者や技術者が室同製系場から直接 知識や情報を獲得したことが確認され 万県。

(3) $\mathrm{F}$ : 明治 26 年現在で 100 釜規模以上の器械 裴系工場か 存在守万県.

(4) 旧県区分の下で工女が派暹されている場合 は，新しい県名に直して表示导机ている。

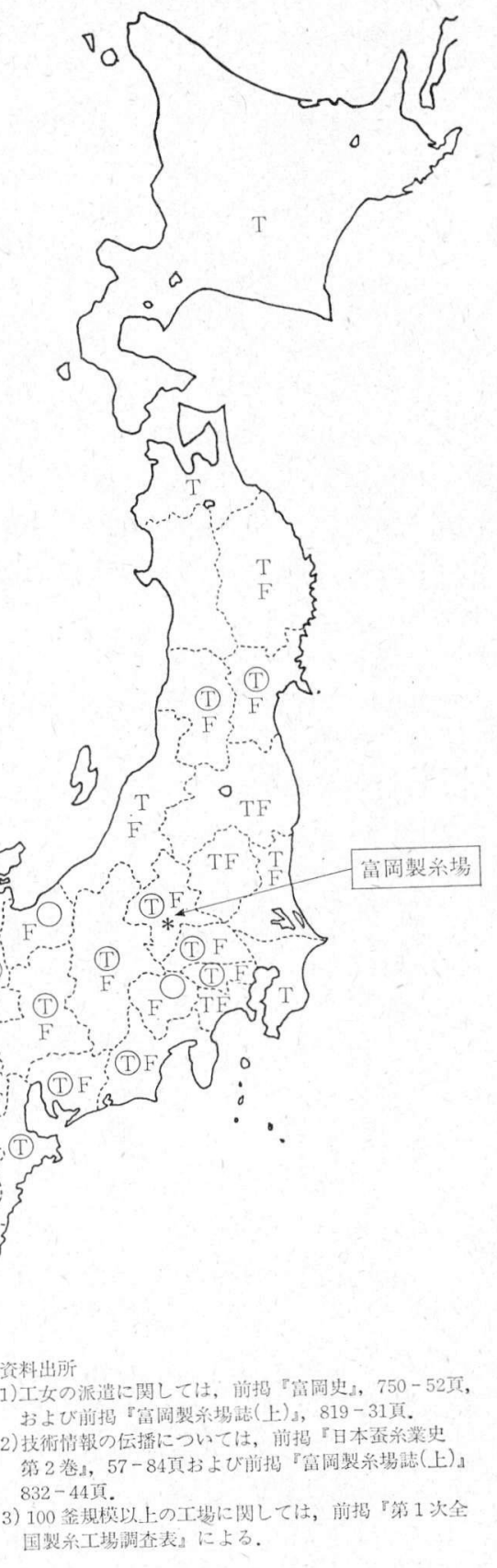
ゆえに, 官営模範工 場たる富岡製系場は, 各府県加らの伝習工 女を受入れただけで なく, 男子の伝習生 制度を設け，また操 業にさしつかえない 限り工場の見学を許 可し技術的相談にも のったのである。今 断片的ながらるてう した事例は，各県の 寔糸業史より数多く 窺うことが出来る22)。 例えば石川の金沢製 系社や兵庫の県立模 範製系場, 福井の勝 山製系会社, 宮城の 広通社等々は，恐ら くその典型といえる が，なかでも長野の 松代製系場 (六工社) については詳しい状 況が分り 23)，当時一 体どのような情報が 最乱必要とされてい たのかが適確に知引 れよう。

また各府県の富岡 製系場に対する伝習 工女の派遣状況は， 『富岡史』の「工女 郷貫調查」によって 概ねの動向が察せら れる。すなわち明治 7 年より 17 (1884) 年.

はもとより, 工程管理や生系整理・検查法のほか 工女に対する繰糸指導や等級決定法等々の情報も またそそこには含まれていたことはいうまでるな い。

22) 藤本実也ほ加(編)『日本奛系業史 第 2 巻』(大 日本奛系会 昭和 10 年), 57-82 頁打よび前揭『富岡 製系場誌(上)』832-46 頁などを参照のこと。なお山梨 県については, 小宮山宽六ほか (編)『山梨県奛系業概 
までの 7 年 (4 年分欠落) 間に, 全国 1 道 3 府 26 県 から延 3,238 人の在籍が確認されている24)。いい か觉れば，欠落があることをも念頭に打く時，全 国の相当広範な地域から伝習工女が派遣されてい たことが知られるのである。な抗この伝習工女に 関して我々は, 次の 3 点を確認して扔く必要があ ろう。まず1つに, 工女達の多くは帰鄉後, 新し い製糸工場で指導的地位に就いたから，伝習工女 といっても実質的には富岡製系場は，製系教婦を

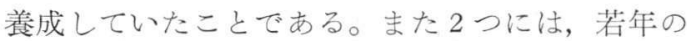
女子が単身で労働移動をすることなぞ考えられな かったその当時, 寄宿舍制度を通じ大量の女子労 働力が移動したことは画期的なことであり，また その後の䋐維女子労働市場の形成に, 大きな貢献 をしたといえよう。さらに3つには，初期の伝習 工女には相当数の下級武士の子女が含まれていた が，彼らの勤労意欲や比較的平等な身分意識は， 国際的視野に立つ時，きわめて注目すべきもので あったと考えられることである。

\section{工場制度の普及と富岡製糸場の触媒機能}

さて次に,こうした広範な伝習工女の派遣や経 営者・技術者の富岡製系場へのアクセスは，果し て真に工場制度の普及と強い関連を有していたの か否かが，問われなけ机ばならないであろう。た だその場合，イタリアの家内工業的技術の影響々 区別する意味で，我々は便宜的に対象を大規模工 場に限定する必要がある。なぜならば近代的製系 工場としての富岡製系場のモデル効果がもしあっ たとするならば，それは組織面でも我々のいう工 場, すなわち複数の分業化された部門と複数の人 的機能を異にする階層を持つ生産組織の経営形態 にも反映されていたはずだからである。その意味 で我々は，人力以外の動力を備え蒸気を熱源とす る 100 釜以上の工場に，さしあたりその資格を見

史』(同刊行会 昭和 34 年), 59 頁。

23）和田英前揭書, 53-108 頁打よび上條宏之註・解 説のほか, 上條宏之前揭書，第 3 章; 江口善次・日高 八十七(編)『信濃虫䒺業史 (下)』(大日本虫系会信濃支 会 昭和 12 年), 155-86 頁など。

24）前掲『富岡史』747-52 頁术よび前揭『富岡製系 場誌(上)』819-31 頁。な打 18 年以降に派遣している 県としては，香川ゃ愛媛，宮崎などがある。
出す。つまり 100 鉒という規模は, 少なくとも数 人の製系教婦を擁し且つ独立の検查部門や選铜部 閒を不可欠とするからである。

今そうした工場の県每の有無が, 明治 26 (1893) 年の『第 1 次全国製系工場調查表』より確認さ 机25)，第 2 図で伝習工女の派遣や経営者・技術者 の工場訪問等の情報と突き合わされている。なお 明治 26 年という時点は，富岡製系場の影響を見 るうえで若干遅すぎるきらいるないわけではない が、こ机が最初の製系工場調查であること，また 途中に松方デフレを含み，この年に民間へ払下げ られていること等を鑑みれば，一応受け入れられ る限界的な時点であろう。さて今，第 2 図の工女 派遣等と大型器械製系工場出現の間の対応関係を, 符号検定に上って確認すれば，県別の対応の有無 は 35 対 12 となり, 明らかに $1 \%$ 水準で十分有意 である。

すなわちこれは，今まで断片的情報によって部 分的に確認されてきた工女派連と大規模製系工場 設立間の相関関係が，より一般的な形で承認され たことを意味している。確かに，例え代置賜や入 間あるいは水沢や松代, 豊岡, 飾磨といった旧県 名時点で工女を派遣していた地域では，その後そ の地域内に大型の器械製糸工場が建設さ机ており, その意味で伝習工女の派遣は明らかに大規模工場 の建設と積極的な関りを持っていたと想定されう る。しかしそれは何も，因果関係の存在を含意す るものではない。なぜならば，そもそる伝習工女 を派遣した背景には，すでに器械製系に対する多 大な関心が存在していたことを意味しているから である。それはすでにその地域が養虫製糸業の中 心地であったことに依るのかるし机ないし，ある いは明治 7 年の「物産表」で必ずしる養蟇製糸の 盛んでない地方でる ${ }^{26)}$, 工女を派遣し大型器械製 系工場を建設している例が少なくないから，意欲 的な殖産興業の精神に基づくるのであったという べきかもしれない。しかしいずれにせよ, 要は富 岡製系場の果した役割は，まさにそうした各地の

25） 脚注 15) 参照。

26）『明治 7 年府県物産表』に関する分析としては, 古島敏雄前掲書が便利である。 
潜在的可能性を実現させる大きな触媒機能に他な らなかったのであり，それがいま工女派遗等の可 視的変数を通じて確認されたのである。

な打富岡製系場によるこの普及効果は，いわゆ る普及理論でいうところの分極化効果 (Hierarchical Effect)の 1つであったと解勫される。すな わちそ机は，各地域に扔ける普及の1次的核ない しセンターの形成であり，それらがまた今度は 2 次的普及を促進したのであった。つまり明治 29 (1896)年にかけて，器械製系工場の平均規模は急 速に拡大し，100 鉒規模以上の工場も急増するが， その各地に抢ける普及の核が明治 26 年頃までに 富岡製系場の影響によって形成されたと解される のである。

\section{4. 工場制度と文化の移植}

\section{富岡製糸場の開業に際しての社会的反応}

当然予想されたこととはいえ，富岡製系場の開 業には，多くの社会的抵抗や反感の克服が何より もまず要請されたのであった。例えばそれは，ブ リューナの宿泊所提供に対する拒否に始まり，妙 義山の材木を工場用建材として使用することへの 抵抗等々，根強い攘夷思想に基づく幾多の偏見と 誤解を $1 つ 1 つ$ 解いてゆかねばならなかったので ある。なかでも最も深刻であったのは，ブドウ酒 を人血とみなす ‘血酒説” や製系場の機械設備に対 するいわれなき雑言等々の流言蜚語の類であった。 それらは工女募集難の主因をなしたともいわれ， 政府自ら血酒説を打消すべく，各県に諭告書を配 付せねばならぬほぞであったのである27)。

確かにそうした数々の流言蜚語は，民衆の無知 蒙昧に基づくところる少なくはなかったが，わず か数年前までは激しい攘夷論が澎湃としていたの であり，その後の急激な転換による文明開化策に 対し大きな抵抗と不信感を露わにしたとて，何ら 不思議はなかったのである。また同時にそうした 初期の工女募集難は，当時全く前例のなかった若

27）例えば大蔵省勧農寮の製系諭告書は, 『群馬県 奛系業沿革調查』(群馬県内務部 明治 36 年), 生糸の 部 63-64 頁に, また長野県の告諭書は, 上條宏之前掲 書, 26-27 頁にみられる。
年婦女子の遠隔地移動や寄宿舎滞在等を含んでい たから，ある意味ではきわめて当然のことでもあ ったといえよう。いずれにせよ，血酒説が横浜や 神戸の外人居留地を中心に早くから全国的に在っ た一方，程なくブドウ酒の試飲や生産が開始され たように，西欧文明に対する反感憎悪は，またそ れへの憧憬礼賛とも表裹一体であったことが知ら 机るべきであるう。

なおこうした洋式文化ないし技術に対する反応 は，群馬県と長野県では大きく異なっていた。例 えば群馬では，富岡製系場に先立つ前橋製糸所の 建設 (明治 3 年)に際しても，すでにより大きな抵 抗があり，ミニーラーや速水堅曹に対する反感や 迫害もまた激しかったが，長野の場合にはそうし た摩擦はほとんど認められていない。それゆえ長 野では，明治 10 (1877) 年までに先の深山田製系場 や六工社のほか，中山社や関製糸所，盛系社，東 行社等々少なくとも23〜24の広義の器械製系所 が建設されたのに対し，群馬ではわずかに水沼製 系場や関根研業社など 4 工場にとどまっていたの である。

こうした群馬と長野の洋式技術の受容に関する 著しい対照性については，これまでのところ必ず しも十分に究明されてきたとはいえない。ただわ ずかに文化変容論の立場から，興味深い仮説が提 示されているにすぎないのである28)。すなわちそ れは，長野で比較的抵抗がなかったのは，技術が 人間や文化と切り離されて受容されたこと，また 導入者の階層が民衆により近く緊張処理がより容 易であったという技術切断仮説と緊張処理の階層 間距離仮説である。確かにこれらは十分説得性を 持つものではあるが, その後の 1 代交雑種や多条 繰糸機の導入に関する両地域の差異等をも念頭に 扔く時29)，こうした外来技術の摂取に関してもま

28）吉田和子「明治初期の製系技術に打ける土着と 外来」『科学史研究』第 II 期 第 16 巻第 121 号 (昭和 52 年)。

29）詳しくは，拙稿「製糸技術の普及伝播について 一多条繰糸機の場合一」『経済研究』第 28 巻第 4 号 (昭和 52 年 10 月) 打よび「㔻品種の改良と普及伝播 -1 代交雑種の場合一」『経済研究』第 31 巻第 1 号 . 第 2 号 (昭和 55 年 1 月・ 4 月)を参照されたい。 
た, 従来の我々のシーソー仮説は十分に妥当する ものと思われる。つまり技術革新の導入は, 競争 的市場にあっては, やや遅れた地域や新興地(こ の場合新寔地たる長野や岐阜)に扔いて,より積 極的に行わ机るといってよい。それゆえ上州座繰 を擁した群馬が，基本的にその改良に向ったのに 対し,より手挽き段階に近かった長野は, 器械製 系技術の捸取にはるかに意欲的に取り組んだので あった。さて元へ戻り, 我々は富岡製系場ないし 工場制度のもつ文化移植的側面についても，簡単 に言及して扔く必要があろう。

\section{工場における労務管理と日曜休日制}

官営模範富岡製系場を設立した政府の直接的意 図は，狭義の器械製系技術ならびに近代的工場制 度の移植に在ったことは疑いない。しかしその意 図とは別にそれらの背後には, 西欧文化が殿然と 存在していたことるまた否定し難い事実である。 例えばその 1 つの典型は，日曜週休制を基本とし た当時の工場の時間管理や労務管理等に見出され るであろう。そして他方, 富岡製系場の開業と ほが期を一にして, 日本政府は暦制の改革を行 い30), 明治 5 年 12 月より太陰太陽暦(天保暦)を 廃し，新たに太陽暦を採用することを決定した。 またそ机に先立つ 4 月には, 学校等を中心に日曜 を休日とする旨も制定している。

もとよりこうした日曜休日制や太陽暦の採用が， 富岡製系場の建設との関連のみで実現されたかけ でないことは，いうまでもない。当時すでに輸出 入が急速に拡大し, 諸外国との接触も増えていた うえ, 官公庁での月給の支払や租税の出納事務, 金融機関に扔ける金利計算等及, 近代的社会制度 の拡充に伴い, 2 年ないし 3 年に 1 度閏亩を置か ねばならない太陰太陽暦では，国際的にもまた国 内的にも種々の不都合が生じざるをえなかったの である31)。一方農業暦としてる，年13ヶ月を含

30) 11 月 9 日に突如詔書が公布された。天保暦の 12 月 3 日をもって, 太陽暦の 6 年 1 月 1 日となる。な おダレゴリ一暦であることの確認は, 明治 31 年 5 月 になって行われる。また明治 6 年は閏年であったから， 官員の給料節約上る早急に実施する必要があった。

31）政府は改暦に際して暦注も禁止したから, 迷信 や縁起と䋓縁し，科学的な生活態度を奖励する意味も
む太陰太陽暦の閏年は, 384 日前後にも及ぶため 季節感8 1 ヶ月程ず机, 暦本来の“生活感覚に調 和した正確な周期性の表現'という基本原則から も，決して秀れたものとはいえなかったのである。

それにも拘らず，民衆の生活に深く浸透してい た太陰太陽暦の急激な改革は, 各地に混乱や暴動 までをひき起こし，新暦は‘耶蘇の暦， ‘毛唐人の 暦〉として排斥無視されたのであった 果地方の小都市や農村では, 祝い日だけでなく旧 暦そのものに依る日常生活が, ほぼ戦後に到るま で根強く残存していたのである33)。るっとるそれ は，攘夷論とか反文明開化思想に基づく旧暦の墨 守というょりは，生活上の慣行や伝統的意識の変 革の難しさを示していると思われる。いま社会一 般がこうした状況にあったから，工場内でも旧暦 の風習や慣行は十分に尊重されたるの〉34), 対外 取引や給与支払等々の関係孔あり, 富岡製系場は いうに及ばず多くの製系工場でも，一般に比較的 早くから新暦が採用されたといわ机る。

他方週とか旬という概念は, 全く自然界の周期 とは関りない生活上の人為的単位であるから，そ こには当然社会の特性や文化がより強く反映され ることとなる。いいかえれば七曜制や日曜週休制 には，より明確にキリスト教文化ないしヨーロッ 八゚的生活様式の色彩が35), 色濃く影を落していた

あったと思われる。な澘法に関する入手容易な啓蒙 書としては, 内田正男『暦と日本人』(雄山閣 昭和 50 年)や渡辺敏夫『暦のすべて』(雄山閣 昭和 55)年など がある。

32) 福井や鳥取, 福岡などでの暴動が有名である。 また当時の典型的な民衆の区応は，小川為治『開化問 答二編』(東京書林 明治 8 年), 上 53 -下 12 頁などに 聟われる。

33) 昭和 21 年文部省調心。柳田国男(編) 前掲書, 382 頁。

34) 例えば当時, 朔望日 $(1$ 日・15日)打よび 28 日を 神の日といって赤飯を炊くことが多かったが，前揭の 『富岡日記』(34-35 頁)でも, その風習が守られていた ことが知られる。なお初代場長の尾高惇忠は, 後に 『大日本暦創行議』なる改暦案を著わしているから, 西欧の太陽暦そのま〉の採用には賛成ではなかったる のと思われる。

35）解放前の中国では, 週および日曜日をそれぞれ 「礼洋」「礼择日」と呼んでいたことでる知られるよう に, それらをやはりキリスト教文化と結びつけて理解 していたことが分る。 
のである。従ってそれは，一部の外国商館や拓雇 い外国人を擁する学校・工場で採用されていたと はいえ，民衆の生活は，従来通りの十干による旬 なり月の朔望(あるいは節気)なりを単位としてい ても一向に支障はなく，西欧的七曜制を導入する 必然性は全くなかったのである。

ただ横須賀製鉄所のような先端的工場では，フ ランス人スタッフは日曜を休日とし，日本人職工 は幕末来の‘ 1 ・6 休日’に従ったからひどく統率 を欠き36), 政府はその後本格的な七曜制の導入 (明治 9 年 4 月) に踏み切らざるをえなかったので ある。しかし官庁や学校，官営工場などをむしろ 例外とし，一般の社会では日曜日は, “耶蘇の休日” とか ‘役所の休日, '学校の休日”などといわ机, その普及浸透には多大な時間を要したのである。 その点では大半の製糸工場も決して例外ではなく, 休日は長らく 1 のとと 15 の日の月 2 回 (3 回の場 合は，1・11・21日)が，標準であった。もっとも これは，郡是製糸や石川組などキリスト教を標榜 する製系工場においてすら，第 2 ・第 4 日㫿日（第 1・第3 日曜日のみ休日)は安息日でなかったこと を想えば，生産第 1 主義の帰結であったというへ きかるしれない。

なお明治 5 年の暦制改革ではまた，てれまでの 農耕社会的時間概念とでもいうへき不定時法が定 時法に改められ，工業化社会建設のための 1 歩が 踏み出されたのであった。しかしそうはいっても, その当時はまだ「時の鐘」によって時刻を知るよ うな生活であったから，時間感覚も粗く，集団労 働に対する時間規律の概念も一般に乏しかった。 従って横須賀製鉄所においてすら，労働時間の観 念や規律は低く，茄率も高かったといわれてい る。それゆえ富岡製糸場の場合，そうした時間意 識の異なる社会からの隔絶を図り，かつ時計によ る敛格な時間管理の下で規律正しい集団作業を遂 行してゆくためにも，大規模な寄宿舎制度は 1 つ

36）坂本藤良『日本雇用史(上)』(中央経済社 昭和 52 年), 26-27 頁ほか。1 2 の 6 日計 6 日を休日とする 1 ・6 休日は，慶応 4 年に制定された。また日曜休日制 は, 小学教則や祭日令 (明治 6 年) で導入されたもの〉 紆余曲折があり，9年から徹底化される。
の必要条件であったと思われる37)。そしてその後 日本の製糸業では，そうした労務管理ないし時間 管理の方向は過度なまでに強調され，先に指摘し たような日本的工場経営の形態が形成されたので ある。

また富岡製糸場では，早くから算術や読み書き を中心に習字，裁縫等の余昵学校が開設 (明治 9 年)されたほか，業余体操の導入や職工救済会の 設置等々，様々な意味でその後の製糸工場の労務 管理の原点ともなるべき措置が講ぜられている。 たがそれらはいずれも西欧的労務管理の移植とい うよりは，近代的工場制度と当時の日本社会との 落差を補填すへく考案された措置であったといっ てよい。いいかえれば，乙れらは工場制度の日本 的な適応化形態であり，その後さらに一層，生産 性に直接関連のない西欧文化的側面は換骨奪胎さ れ38)，次第に日本的工場経営・労務管理が形成さ れてゆくのである。その意味に执いて，生産第 1 主義の日本の工場システムに，日曜週休制等の新 しい社会制度が取入机ら机てゆくのは，日本の社 会全体がその方向に変容してくるまで俟たねばな らなかったのである。

\section{5. 技術格差と工場組織の定着一結びに代えて一}

以上我々は 2 つの問題意識の下で，富岡製糸場 に対する西欧製系技術とその生産組織の移転なら びにそれに伴う普及効果の問題を考察してきた。 その結果明らかにされたことは，まず第 2 の分析 課題についていえば，近代的工場制度の普及・定 着という側面への効果をる勘案する時, 富岡製系 場が日本の製糸業の近代化に果した役割は，きわ めて大きなるのであったと考えられることである。 そ机は伝習工場としての製系教婦の育成に始まり, 近代的生産組織に都ける品質管理や労務管理の在

37）綿紡績業の寄宿舎制度は, アメリカのローウェ ルに範をとるとともに, 富岡製系場のそれをも参考に したといわれる。「工女寄宿所規則」などの精神は, 明らかに受け継がれていたといえよう。

38)このように文化的側面を切り離し, 生産第 1 主 義の下で自国文化の中へ受容してゆくことが多くの面 で可能であるならば,ややはり産業主義化は多完化の可 能性を秘めているといわねばならないであろう。 
り方に関するモデル提示の効果等々, その後の器 械製糸工場の建設に大きな影響を与えたのであっ た。また全国各地に後の普及伝播の核とるなるべ き比較的大型の器械製系工場が, 富岡製系場の触 媒機能を介して広範に設立されたことも, 統計的 に確認された。

な扔そこで併せて指摘さるべきは, 工場制度の 普及に際して, 簡易器械製系技術のみならず, 工場 の経営管理ついても日本的な労働強化型の管理形 態が生み出されていたことである。これは基本的 に，導入さ机た西欧製系技術と在来技術との技術 格差が小さく且つ製系技術に分割可能性(Divisibility)があったことにより，比較的容易に市場 条件人の適応化が可能であったためと考えてよい。 その他我々は, 富岡製系場の技術や組織は, 当時 のヨーロッパの製系業と比較してるきわめて先端 的なるのであったこと，また仮りにそれが日本的 な工場形態に簡素化されたものであっても, 器械 製系技術ならびに工場生産形態は，その生産シス テムとしての潜在的可能性に打いて, 座繰生産組 織とは本質的に大きく異なることなどが，併せて 明らかにされたのである。

次に第 1 の分析課題たるファースの仮説との関 連でみた日本に扔ける工場制度の受容過程につい ていえば，ファース仮説は基本的には受け入れる 机るるの〉 ${ }^{39)}$ ，部分的には技術格差仮説などによ ってより精緻化される必要があると考えられるこ とである。なお本来ファースの仮説は, ニニージ ーランドのマオリ族が 19 世紀にヨーロッパ文明・ 文化と接触した際の文化受容の形態に関する仮説 であるが，それはその後ホゼリッッ(Bert Hoselitz)らによって, 現代の経済発展過程に打ける文 化変容の問題あるいは産業技術導入の社会学的側 面として，より広い文脈に扔いて捉えられている。 すなわちそれは, 異質の文明や文化との接触受容 に際しては，まず最も低次な商品レベルから始ま り商品 $\rightarrow$ 技術 $\rightarrow$ 組織制度 $\rightarrow$ 精神文化という段階な いし時間的継起を経て受容されるとする仮説であ る。

39）脚注 4)を参照のこと。
いま我々の器械製系工場制度という４者を含ん だパッケージの導入についてみ机ぱ，概ねこの仮 説は支持されるといってよい。すなわち生系とい う商品は，すでに日本社会にとって既知であった から，程なく適正技術化を含んだ器械製系技術の 定着 (明治 20 年代末)が起こり, 続いてやはり日 本の市場構造や社会構造への適応化を含んだ日本 的工場制度が成立(明治 30 年代末)したのである。 しかし日曜週休制やその他の西欧的労務管理の慣 行は，社会全体での受容条件が整うのを俟っては じめて工場制度の中へ取り入れられる(戦後)など, その意味では技術や組織(狭義の) は, そうした文 化的側面から切り離された形で受容されたという こともまた可能であろう。

つまりこの限りでは, ファースの仮説は完全に 成立しているといってよい。しかしそこにはすで に指摘した如く，導入技術の特性に関する 1 つの 前提条件が存在していたのである。すなわち器械 製系技術の場合，技術格差が小さく且つ分割可能 であったがゆえこの仮説の基本型は成立してい たともいいうるのである。つまり今もし導入技術 の技術格差が十分に大きいとするならば，市場へ の調整ではなく市場側がら市調整が必要であり40), 従って第 2 ・第 3 の局面は同時に起こることも十 分予想されうるのである。このようにファースの 仮説は, 若干の留保条件を置くなり, あるいはよ り具体性の高い仮説などによって補強される必要 があると思われる。

そしてまさにこの点で, 例えば今日 1 つのパッ ケージとして低開発諸国に多数導入されているプ ラント設備やその組織が, 必ずしもうまく機能し ていないことを理解するためにも, ファース仮説 の精緻化が期待されるのである。すなわち問題は, 技術や組織の単なる受容という理解ではなく, そ の過程に和ける社会や市場の調整能力の問題であ り, 且つまたそ机らに対する適応化能力の問題で るあって，そうした具体的側面にこそより大きな 照準が当てら机ることが, 緊急に望まれているこ となのである。

(一橋大学経済研究所)

40）詳しくは，脚注 16)の文献を参照されたい。 